\title{
PERENCANAAN FRAME DAN RANGKAIAN ELECTRIC BERBASIS HYBRID-ELECTRIC VEHICLES (HEVS) MENUJU UNDIKSHA GO GREEN
}

(Studi Kasus di Universitas Pendidikan Ganesha Singaraja)

\author{
Jurusan Pendidikan Teknik Mesin, Fakultas Teknik dan Kejuruan \\ Universitas Pendidikan Ganesha \\ Singaraja, Indonesia \\ email: rihendra dantes@yahoo.co.id
}

\begin{abstract}
Abstrak
Hybrid merupakan salah satu solusi untuk menciptakan transportasi yang efisien dan ramah lingkungan. Berdasarkan pra-survey yang dilakukan, keadaan lingkungan Universitas Pendidikan Ganesha sangat tidak kondusif artinya, lalu lintas di dalam kampus yang bising dan tidak kondusif menyebabkan kenyamanan dalam melakukan proses belajar mengajar bias dibilang tidak maksimal. Melalui proposal ini direncanakan sebuah transportasi lokal di lingkungan Universitas Pendidikan Ganesha untuk menciptakan lingkungan kampus lebih nyaman dan kondusip. Lebih lanjut, topik dalam penelitian ini: Perencanaan Transportasi Lokal Berbasis Hybrid-Electric Vehicles (HEVs) Ramah Lingkungan. (Studi Kasus di Universitas Pendidikan Ganesha Singaraja).

Perancangan transportasi lokal ini dilakukan melalui 4 fase, yaitu: (1) Survey dan Analisis Kondisi Umum, (2) Studi Pustaka (Kajian Teori dan Emperik), (3) Analisis Proses, serta (4) Perancangan frame Hybrid-Electric Vehicles, Electric System, Internal Combustion Engine.

Kata Kunci : Transportasi Lokal, Universitas Pendidikan Ganesha, Hybrid-Electric Vehicles (HEVs),
\end{abstract}

Abstract
Hybrid is one of the solutions to create efficient transport and environmentally. Based on the pre-survey, environmental conditions in the Ganesha Education University, on-campus traffic is noisy and not conducive cause comfort in the teaching and learning process is arguably no maximum. This study to plan a local transportation in the Ganesha Education University to create a more comfortable environment and conducive environment.

This study uses research $R \& D$, where local transportation planning is conducted through four phases : 1) Survey and Analysis of the General Conditions, (2) Library Studies (Theory and Assessment Emperik), (3) Process Analysis, and (4) The design of the frame and Hybrid-Electric Vehicles Electric Vehicles System.

Keywords: Local Transport, Ganesha Education University, Hybrid-Electric Vehicles (HEVs) 


\section{PENDAHULUAN}

Teknologi otomotif merupakan salah satu teknologi yang berkembang dengan sangat cepat. Pesatnya perkembangan otomotif akan membuka peluang dan tantangan untuk menciptakan (to create), teknologi-teknologi dalam bidang otomotif secara tepat dan akurat. Transportasi merupakan suatu hal yang sangat berharga di era globalisasi untuk menyokong indivu dalam melakukan suatu aktivitas. Pengembangan-pengembangan teknologi dalam bidang otomotif dikembangan untuk mencari sebuah energy terbrukan sehingga efisiensi penggunaan bahan bakar dan menekan emisi gas buang pembakaran sehingga polusi udara bisa diminimalisir. Menipisnya cadangan energi minyak bumi dan tingginya tingkat polusi udara yang disebabkan oleh pemakaian kendaraan bermotor merupakan permasalahan yang harus segera diatasi. Salah satu solusi yang paling memungkinkan untuk saat ini adalah Hybrid Electric Vehicles (HEVs). HEVs mengkombinasikan mesin bakar dan motor listrik untuk meminimumkan penggunaan mesin bakar sehingga akan dicapai tingkat konsumsi bahan bakar dan tingkat polusi yang rendah.

Seperti yang dijelaskan di atas, perkembangan kendaraan listrik terakhir ini memang dipicu oleh persoalan ketersediaan sumber energi dan dampak pemakaian motor bensin terhadap lingkungan. Dalam konteks motor listrik, khususnya motor sinkron magnet permanen, sudah berhasil dikembangkan motor yang kompak dengan output yang besar serta memenuhi kriteria aplikasi otomotif. Bidang elektronika daya juga berkembang sehingga dihasilkan komponen dan sistem konversi elektronik yang kompak dengan efisiensi konversi yang tinggi, handal serta tetap ekonomis. Sedang perkembangan mikroelektronika telah memungkinkan penggunaan teknik kendali lanjut dalam mengatur motor listrik sehingga dihasilkan unjuk kerja yang tinggi.

Dengan demikian dapat dilihat bahwa kendaraan listrik merupakan salah satu solusi penting untuk mengatasi persoalan yang berhubungan dengan polusi lingkungan, keterbatasan dan semakin berkurangnnya persediaan bahan bakar konvensional, dan pemanasan global akibat tingginya penggunaan bahan bakar berbasis fosil dalam peralatan transportasi. Untuk itu perlu dilakukan upaya-upaya untuk mendukung perkembangan kendaraan listrik, khususnya di Indonesia.

Hybrid-Electric Vehicles (HEVs) merupakan penggabungan manfaat dari mesin konvensional (bensin) dan motor Electric (listrik) dan dapat dikonfigurasi untuk mendapatkan tujuan yang berbeda, seperti meningkatkan ekonomi bahan bakar, daya yang meningkat, atau daya tambahan untuk perangkat elektronik dan alat-alat listrik. Keuntungan dari mobil ini selain efesiensi bahan bakar konvensional (bensin), mobil ini merupakan mobil ramah lingkungan dimana penggunaan bahan bakar konvensional akan di hemat hingga $50 \%$ dengan menggunakan penggerak motor listrik. Pergerakan kendaraan dengan motor bahan bakar konvensional (bensin) ini akan menghasilkan energy listrik yang akan tersimpan di battery sehingga jelas terlihat bahwa akan tereduksinya penggunaan bahan bakar konvensional (bensin) dan menurunnya pencemaran udara. Polusi suara yang di hasilkan akan lebih kecil dari kendaraan konvensional, sehingga kenyamanan lingkungan lebih di tingkatkan. Melihat peningkatan volume pemakaian kendaraan di lingkungan kampus Universitas Pendidikan Ganeha Singaraja. Untuk itu dipandang perlu dilakukan sebuah perancangan transportasi lokal di lingkungan Universitas pendidikan Ganesha. Sasaran yang ingin dicapai dalam perancangan transportasi lokal ini, secara umum dapat dirumuskan sebagai berikut: "perancangan model transportasi lokal berbasis Hybrid-Electric Vehicles (HEVs) ramah lingkungan untuk mereduksi pencemaran udara dan juga mereduksi penggunaan bahan bakar konvensional (bensin) dalam rangka mewujudkan 
kenyamanan lingkungan, dengan mengambil Universitas pendidikan Ganesha sebagai pilot project".

Secara substansial, tujuan dari perancangan transportasi lokal ini dapat diformulasikan sebagai berikut:

1. Terciptanya sebuah rancangan transportasi alternatif berbasis HybridElectric Vehicles (HEVs) dalam rangka efisiensi penggunaan bensin di lingkungan undiksha.

2. Menciptakan lingkungan yang Nyaman di dalam kampus Undiksha

3. Mengurangi tingkat polusi udara di lingkungan kampus Undiksha

Adapun beberapa manfaat yang didapatkan dari perancangan model transportasi lokal berbasis Hybrid-Electric Vehicles (HEVs) ini adalah :

1. Bagi efesiensi penggunaan energi konvensional (bensin), rancangan transportasi ini akan meberi kesadaran dalam menggunakan energi konvensional dalam bertransportasi baik masyarakat umum atau individu atau kelompok individu di lingkungan UNDIKSHA yang dijadikan sebagai pilot project.

2. Bagi pengurangan polusi udara, perancangan transportasi lokal ini akan sangat mereduksi polusi udara karena transportasi ini berbasis Hybrid-Electric Vehicles (HEVs) artinya kendaraan ini $50 \%$ digerakan dengan menggunakan motor listri. Sehingga polusi udara dan polusi suara dapat di tekan.

3. Bagi khalayak umum (masyarakat luas), perancangan transportasi lokal ini akan menjadi masukan untuk mengetahui manfaat dari transportasi berbasisi Hybrid-Electric Vehicles (HEVs) yang nantinya sebagai bahan untuk pertimbangan dalam memilih jenis transportasi yang akan digunakan .

\section{METODE}

Hybrid-Electric Vehicles (HEVs) merupakan teknologi yang menggabungkan manfaat dari mesin konvensional (bensin) dan motor Electric (listrik) sehingga dapat menghemat pemakean bahan bakar minyak. Dengan meminimalkan pemakaian bahan bakar maka nilai ekonomis dari oprasinya dapat di tekan. Keuntungan darimobilini selain efesiensi bahan bakar konvensional (bensin) mobil ini merupakan mobil ramah lingkungan dimana hasil putaran mesin motor bakar akan dimanfaatkan dan disimpan dalam accu kemudian dipergunakan sebagai sumber energi motor listrik.Dari perancangan ini akan diharapkan dapat menghemat samapai $75 \%$ pemakaian bahan bakar minyak.

Pencemaran udara dewasa ini sangat mempengaruhi peningkatan pemanasan gelobal. Kontribusi yang paling besar menyumbangkan polutan adalah pada sektor transportasi. Dari data emperik yang di tunjukkan Claus Doll, tercatat mobil dan truk bertanggung jawa batas hampir $25 \%$ dariemisiCO2, dan transportasi utama lainnya

menyumbangkan pulutan mencapai $12 \%$ lagi. polusi udara ini $50 \%$ terjadi di daerah perkotaan.

Hybrid teknologi adalah sebuah penggabungan duaatau lebihsumberdaya yang berbedasebagai tenaga penggerak kendaraan bermotor. Setiap transportasi yang menggunakan sumber listrik dua atau lebih diakui sebagai mobil hybrid. Manfaat utama dari teknologi mobilhybrid iniadalah konsumsibahan bakaryang lebih rendah sehingga tingkat emisinya juga rendah. Dengan terus meningkatnya teknologi terbaru, sistem hybrid tersebut juga dapat memberikan kinerjayang lebih baik.

Mobil hibrida juga dikategorikan menjadi beberapa jenis. Pada dasarnya, ada tiga jenis mobil hibrida: hibrida penuh, hybrid paralel dan mobil hibrida seri. Tipe pertama adalah mobil hibrida penuh. Karakteristik yang jelas dari jenis seperti mobil hibrida masih bisa menggerakkan mobil ke depan ketika berjalan perlahanlahan tanpa asupan bensin. Jenis lainnya adalah mobil hybrid paralel. Tipe ini menggunakan dua motor yang bekerja 
sama. Motor pertama ini didukung oleh bensin dan lainnya ini didukung oleh baterai listrik. Hybrid mobil tipe seri, pada tipe ini bahan bakar terutama hanya digunakan untuk menyalakan mesin, sementara sumber dayanya adalah pemanfaatan putaran mesin yang dipergunakan untuk memutar generator segai sumber energy listrik yang dipergunakan untuk mengisi kapasitas baterai. Energy yang tersimpan pada batrai dipergunakan untuk sumber energy pada motor listrik sehingga didapatkan motor listrik yang tanpa polutan udara dan polusi suara. Dewasa ini jenis mobil hybrid yang ditawarkan sebagian besarsaat iniadalah jenis paralel. Dengan demikian, perkembangan mobil hybrid merupakan terurobosan teknologi baru dalam bidang otomotif untuk reduksi pemanasan global, karena Industri otomotif umumnya dianggap sebagai salah satu kontributor utama pemanasan global.

Ada beberapa perspektif yang mendukung dan menjadi landasan ide dalam perancangan Hybrid-Electric Vehicles (HEVs) ini diantaranya sebagai berikut :

\section{Perspektif dari Efek Lingkungan}

Kemungkinan besar kerusakan ekologi telah dikaitkan dengan perubahan atmosfer bumi dan bagaimana perubahan iklim dipengaruhi oleh beberapa aktivitas masyarakat sebagai aktivitas standar berkendara. Individu dalam melakukan aktivitas berkendara secara tidak sadar telah membuang gas berbahaya ke udara sehingga efek rumah kaca itu muncul, dengan demikian tingkat polusi di udara akan semakin meningkat dari hari ke hari. Ada bebarapa gas berbahaya yang secara tidak langsung dilepaskan ke atmosfer, seperti karbon dioksida (CO2), chlorofluorocarbons(CFC). Gas ini dapat mengakibatkan suhu udara pada permukaanbumi. Panas yang terperangkap dan tidak dapat keluar dari atmosfer akan menimbulkan reaksi perubahan iklim yang tidak menentu dari hari kehari yang kita sebut sebagai pemanasan global. Beberapa pengaruh dari pemanasan global ini harus kita waspadai seperti: mecairnya es di kutub yang dapat mengakibatkan aniknya permukaan air laut. Sehingga dapat menyebabkan intensitas banjir yang tinggi. Banyak ahli menyatakan pada tahun 2025 permintaan energy dunia diproyeksikan menjadi 3,5 kali lebih besar dibandingkan dengan tahun 1990, dengan emisi CO2 50\% lebih tinggi tiap tahunnya.

Mengacu pada kajian emperik dari hasil penelitian Michael Beliveau dkk, menyatakan bahwa emisi yang terbuang ke udara akibat dari menyalanya satu kendaraan dengan bahan bakar konvensional dapat diuraikan sebagai berikut: gas Nitrogen (N2), karnbon dioksida (CO2), karbonmonoksida (CO), hidrokarbonatau senyawa organik volatil (VOC), dan nitrogen oksida (NO dan NO2, bersama-sama disebut NOx). Lebih jelas dapat dilihat pada table dibawah senyawa kimia yang di hasilkan dari pembakaran motor dengan bahan bakar koncvensional.

Tabel 1.

\begin{tabular}{|c|c|c|}
\hline Air Pollutant & $\begin{array}{l}\text { Proportion from On- } \\
\text { road Motor Vehicles }\end{array}$ & Note \\
\hline $\begin{array}{l}\text { Oxides of Nitrogen } \\
\qquad\left(\mathrm{NO}_{\mathrm{x}}\right)\end{array}$ & $34 \%$ & $\begin{array}{l}\text { precursor to ground-level ozone (smog), which damages the } \\
\text { respiratory system and injures plants }\end{array}$ \\
\hline $\begin{array}{l}\text { Volatile Organic } \\
\text { Compounds (VOC) }\end{array}$ & $34 \%$ & $\begin{array}{l}\text { precursor to ground-level ozone (smog), which damages the } \\
\text { respiratory system and injures plants }\end{array}$ \\
\hline $\begin{array}{l}\text { Carbon Monoxide } \\
\qquad(\mathrm{CO})\end{array}$ & $51 \%$ & contributes to smog production; poisonous in high concentrations \\
\hline $\begin{array}{c}\text { Particulate Matter } \\
\left(\mathrm{PM}_{10}\right)\end{array}$ & $10 \%$ & $\begin{array}{l}\text { does not include dust from paved and unpaved roads, which are } \\
\text { the major source of particulate matter pollution ( } 50 \% \text { of the total) }\end{array}$ \\
\hline Carbon Dioxide $\left(\mathrm{CO}_{2}\right)$ & $33 \%$ & thought to be primary contributor to global warming \\
\hline
\end{tabular}

\section{Perspektif perluasan mobil hybrid sebagai transportasi lokal alternatif \\ Penerapan penggunaan transportasi}

berbasis hybrid sudah cukup luas, tetapi tidak mengurangi permintaan dunia terhadap bahan bakar yang habis pakai atau bahan bakar konvensional. Secara pangsa pasar kendaraan berbasis hybrid masih kurang dalam jumlah quantitasnya yang tersedia di pasaran, karena perusahaan- 
perusahaan otomotif terus bereksperimen terhadap transportasi ramah lingkungan satu ini.

Maka dari itu melaluipenelitian dalam perancangan transportasi lokal berbasis teknologi hybrid, peneliti dapat berharap rancangan ini akan berhasil sebagai dasar berpijak bagi peneliti untuk mengembangkan alternative trasportasi local berbasis Hybrid-Electric Vehicles (HEVs). Penelitian ini dadasarkan pada kepedulian peneliti terhadap kenyamanan lingkungan, walaupun peneliti sadar akan banyak pro dan kontra terkait perancangan transportasi ini untuk alternatif kendaraan di lingkungan Universitas Pendidikan Ganesa yang di jadikan pilot project.

Mengangkat topik penelitian ini juga akan mengangkat beberapa pertanyan seperti bagaimana emisi hybrid dibandingkan dengan pembakaran bahan bakar konvensional. Disamping itu akan muncul pertanyaan berapa besar daya yang dihasilkan motor listrik mampu menggerakkan sebuah kendaraan dengan kapasita penumpang yang dapat dikatakan cukub banyak. Dari dasar pertanyaan tersebut untuk melihat untuk lebih rinci ada beberapa motor listrik yang menjadi pertimbangan peneliti untuk perancangan ini. Spesifikasi motor listrik sebagai berikut:

\begin{tabular}{|c|c|}
\hline Motor & Spesifikasi \\
\hline $\begin{array}{l}\text { Motor DC Seri } \\
\text { (dengan dan tanpa }\end{array}$ & $\begin{array}{l}\text { Daya: } 3.5 / 3.6 / 4.3 / 40 / 49 \mathrm{~kW} \mid 70 \mathrm{HP} \\
\text { Tegangan DC Bus: } 48 / 72 / 288\end{array}$ \\
\hline sikat) & $\begin{array}{l}\text { Pendingin: udara atau cair } \\
\text { Aplikasi: EV Plus, Chrysler TEV, } \\
\text { Clio, EV-50 }\end{array}$ \\
\hline Motor Induksi & $\begin{array}{l}\text { Daya: } 75 / 137 \mathrm{HP} \mid 40 \mathrm{~kW} \\
\text { Tegangan DC Bus, Pendingin: cair } \\
\text { Aplikasi: Ecostar, Ford Ranger, } \\
\text { Impact, EV-50 }\end{array}$ \\
\hline Motor Sinkron & Daya: \\
\hline Magnet & $2 / 18.5 / 24 / 35 / 50 / 62 / 70 / 105 / 123$ \\
\hline \multirow[t]{5}{*}{ Permanen } & $\mathrm{kW}$ \\
\hline & Tegangan DC Bus: \\
\hline & $72 / 120 / 240 / 244 / 288 / 330 / 345 \mathrm{~V}$ \\
\hline & Pendingin: cair \\
\hline & Aplikasi: micro car hingga truck \\
\hline
\end{tabular}

\section{Perspektif kelayakan teknis}

Transportasi berbasis HybridElectric Vehicles (HEVs) adalah sebuah model kendaraan yang menggunakan sistem penyimpanan energi dengan isi ulang pada battery sebagai penyimpan daya untuk melengkapi energi bahan bakar konvensional (fosil) untuk penggerak kendaraan. Mesin hybrid yang lebih kecil dan lebih efisien dibandingkan mesin bahan bakar konvensional lebih representative untuk dikembangkan sehingga menjadi sebuah salah satu transportasi pilihan untuk masyarak umum.

Beberapa kendaraan hibrida yang berkembang dewasa ini banyak menggunakan beberapa kombonasi menggunakan pengereman regeneratif untuk menghasilkan listrik saat bepergian. The "Kendaraan Hybrid" juga dapat merujuk ke mesin kendaraan yang menggunakan kombinasi bahan bakar yang berbeda seperti minyak bumi dan etanol.

Untuk itu dipandang perlu dilakukan sebuah perancangan transportasi lokal di lingkungan Universitas pendidikan Ganesha.

Membangun sistem transportasi alternatif sehingga dapat mewujudkan kenyaman lingkungan di Universitas Pendidikan Ganesha. Dengan demikian akan terwujud kendaraan alternatif yang memobilisasi civitas akademika di lingkungan kampus.

\section{HASIL DAN PEMBAHASAN}

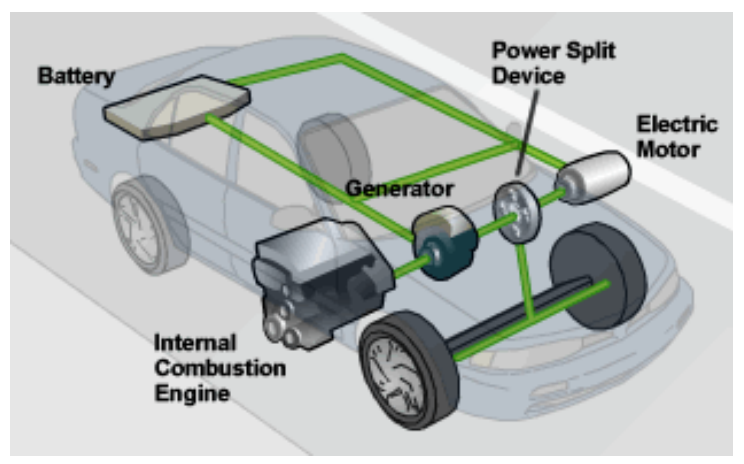




\section{Hasil Rancangan Frame Kendaraan Hybrid-Electric Vehicles (HEVs)}

\begin{tabular}{|c|c|c|c|}
\hline \multicolumn{4}{|c|}{$\begin{array}{l}\text { Model name: body holow } \\
\text { urrent Configuration: Default }\end{array}$} \\
\hline \multicolumn{4}{|c|}{ Solid Bodies } \\
\hline $\begin{array}{c}<L_{\text {SldBd Mdnf }} \\
\text {-SldBd_- } \\
\mathrm{Nm} />\end{array}$ & $\begin{array}{l}\text { Treated } \\
\text { As }\end{array}$ & $\begin{array}{l}\text { Volumetric } \\
\text { Properties }\end{array}$ & $\begin{array}{c}\text { Documen } \\
t \\
\text { Path/Dat } \\
e \\
\text { Modified }\end{array}$ \\
\hline $\begin{array}{c}\text { Boss- } \\
\text { Extrude4 } \\
4\end{array}$ & $\begin{array}{l}\text { Solid } \\
\text { Body }\end{array}$ & $\begin{array}{c}\text { Mass:193. } \\
011 \mathrm{~kg} \\
\text { Volume:0.0 } \\
250663 \\
\mathrm{~m}^{\wedge} 3 \\
\text { Density:77 } \\
00 \mathrm{~kg} / \mathrm{m}^{\wedge} 3 \\
\text { Weight:189 } \\
1.5 \mathrm{~N}\end{array}$ & $\begin{array}{c}\text { L:Ihamid } \\
\text { bodylbod } \\
y \\
\text { holow.SL } \\
\text { DPRT } \\
\text { May 21 } \\
\text { 13:29:00 } \\
2013\end{array}$ \\
\hline $\begin{array}{c}<L_{\text {ShlBd Mdnf }} \\
\text { - }_{\mathrm{Nm} />}\end{array}$ & $\begin{array}{l}<L_{\text {_Mdl }} \text { Md } \\
\mathrm{n} \text { ShlB } \\
\text { d_Fr/s }\end{array}$ & $\begin{array}{c}<L_{\text {Shd Mlnf }} \\
\text { ShIBd_Vol } \\
\text { Prop/> }\end{array}$ & $\begin{array}{c}<\text { L_Mdln } \\
\text { ShlBd } \\
\text { DtMd/> }\end{array}$ \\
\hline $\begin{array}{c}<L_{\text {_Mdlnf }} \\
\text { CpBd_N } \\
\mathrm{m} />\end{array}$ & \multicolumn{3}{|c|}{$<$ L_Mdlnf_CompBd_Props/> } \\
\hline $\begin{array}{c}<L_{\text {_Mdlnf }} \\
-\mathrm{BmBd}_{-} \\
\mathrm{Nm} />\end{array}$ & $\begin{array}{l}<L_{-} \text {Mdl } \\
n_{-}{ }_{-} m B \\
d_{-} \mathrm{Fr} />\end{array}$ & $\begin{array}{c}<\mathrm{L} \text { MdInf } \\
\text { BmBd_Vol } \\
\text { Prop/> }\end{array}$ & $\begin{array}{c}<\mathrm{L} \text { _Mdln } \\
\text { BmBd_- } \\
\text { DtMd/> }\end{array}$ \\
\hline
\end{tabular}

Dari running software solidworks dengan mensimulasikan rancangan frame perancangan kendaraan Hybrid-Electric Vehicles didapatkan data-data sebagai berikut:

- Massa frame Kendaraan : 193, 011

$\mathrm{Kg}$

- Volume batang frame : 0,0250663 $\mathrm{m}^{3}$

- Density frame kendaraan: 7700 $\mathrm{kg} / \mathrm{m}^{3}$

- Weigth frame kendaraan : $1891,5 \mathrm{~N}$

\begin{tabular}{|c|c|c|c|}
\hline \multirow[t]{2}{*}{ Model Reference } & \multicolumn{2}{|c|}{ Properties } & Components \\
\hline & $\begin{array}{r}\text { Name: } \\
\text { Model type: } \\
\text { Default failure } \\
\text { criterion: } \\
\text { Yield strength: } \\
\text { Tensile strength: }\end{array}$ & $\begin{array}{l}\text { Alloy Steel } \\
\text { Linear Elastic } \\
\text { Isotropic } \\
\text { Max von Mises } \\
\text { Stress } \\
6.20422 \mathrm{e}+008 \\
\mathrm{~N} / \mathrm{m}^{\wedge} 2 \\
7.23826 \mathrm{e}+008 \\
\mathrm{~N} / \mathrm{m}^{\wedge} 2\end{array}$ & $\begin{array}{l}\text { SolidBody 1(Boss- } \\
\text { Extrude44)(body } \\
\text { holow) }\end{array}$ \\
\hline
\end{tabular}

Lebih lanjut dapat diketahui juga material properties dari perancangan fram kendaraan berbasis hybrid-electric vehicles seperti out put software solid works di atas. Secara rinci material properties frame kendaraan sebagai berikut:

- Row material frame kendaraan : Alloy

Steel

- Model freme kendaraan : Linear Elastic Isotropic

- Kreteria kegagalan fare kendaraan :

Max von Mises Stress

- Yield strength : 6. 20422 e+008 N/m2

- $\quad$ Tensile Strength : 7,23826e+008 N/m2

Dengan demikian dari segi material spesifikasi secara keseluruhan perancangan frame kendaraan hybrid ini sudah diketahui berdasarkan simulasi yang dilakukan peneliti dengan bantuan software solid works. Dan juga peneliti sudah mengetahui kekuatan yield dan kekuatan tarik frame kendaraan yang dirancang. 
Loads and Fixtures

\begin{tabular}{|c|c|c|}
\hline $\begin{array}{c}\text { Fixture } \\
\text { name }\end{array}$ & Fixture Image & Fixture Details \\
\hline & & Entities: 10face(s) \\
Type: Fixed Geometry
\end{tabular}

\begin{tabular}{|c|c|c|}
\hline Load name & Load Image & Load Details \\
\hline & & Entities: 3 face(s) \\
Type: Apply normal force \\
Value: $4500 \mathrm{~N}$
\end{tabular}

Dengan menggunakan simulasi ini frame kendaraan hybrid-electric vehicles dengan software yang sama juga dilakukan pembebanan merata pada dengan tidak mengunci geometri freme kendaraan untuk melihat pembebanan pembebanan kritis yang terjadi pada rancangan frame kendaraaan berbasis hybrid-electric vehicles yang di rancang peneliti.

Secara rinci distribusi pembebanan akan di running dengan software yang sama untuk melihat tegangan dan regangan yang terjadi pada setiap titik fream kendaraan, dan menghasilkan seperti dibawah ini:
Mesh Information

\begin{tabular}{|l|l|}
\hline Mesh type & Solid Mesh \\
\hline Mesher Used: & Standard mesh \\
\hline Automatic Transition: & Off \\
\hline Include Mesh Auto Loops: & Off \\
\hline Jacobian points & 4 Points \\
\hline Element Size & $56.7451 \mathrm{~mm}$ \\
\hline Tolerance & $2.83726 \mathrm{~mm}$ \\
\hline Mesh Quality & High \\
\hline
\end{tabular}

Mesh Information - Details

\begin{tabular}{|l|l|}
\hline Total Nodes & 22323 \\
\hline Total Elements & 11438 \\
\hline Maximum Aspect Ratio & 72.674 \\
\hline \% of elements with Aspect Ratio $<3$ & 4.97 \\
\hline$\%$ of elements with Aspect Ratio $>10$ & 67.2 \\
\hline$\%$ of distorted elements(Jacobian) & 0 \\
\hline Time to complete mesh(hh;mm;ss): & $00: 00: 10$ \\
\hline Computer name: & FDM3-PC \\
\hline
\end{tabular}

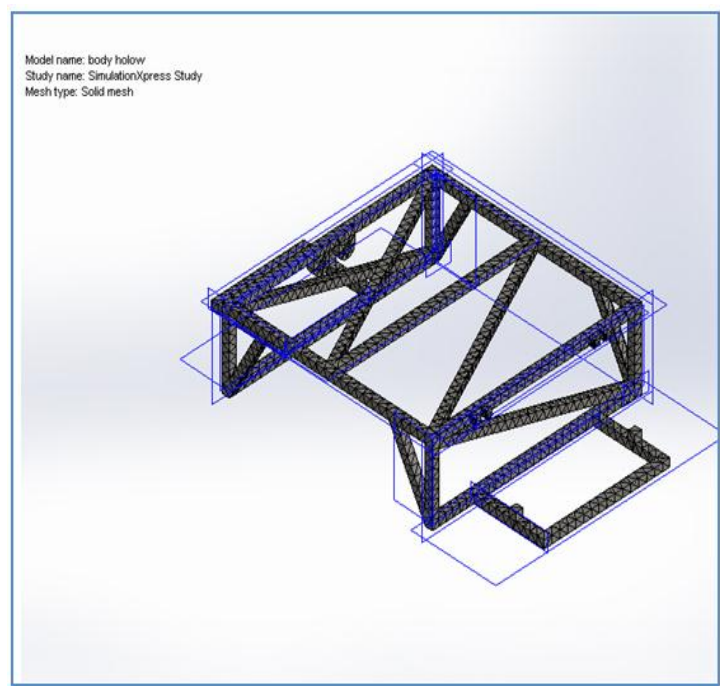




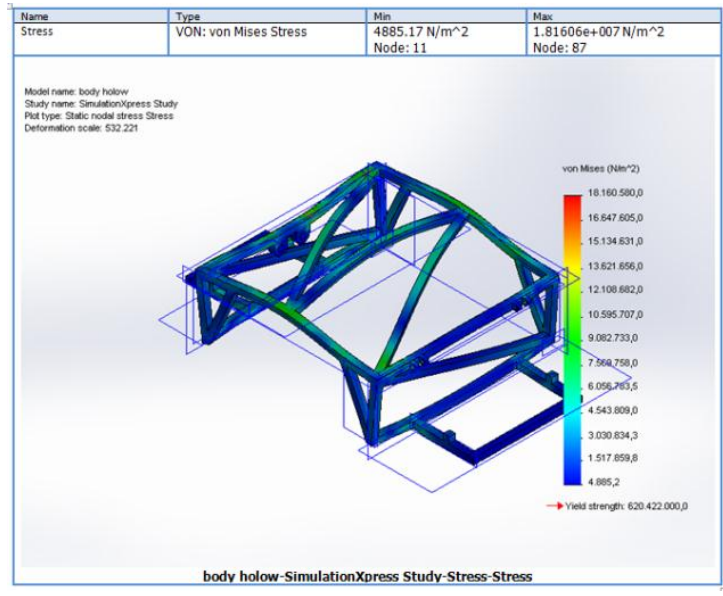

Dari hasil output yang di hasilkan software didapatkan tegangan maksimun dan tegangan minimum yang diijinkan dalam pembebanan perancangan freme kendaraan hybrid ini. Dengan melihat gambar di atas, terlihat jelas bagian-bagian frame yang mempunyai tegangan-tegangan akibat pembebanan ditunjukkan dengan warna hijau.

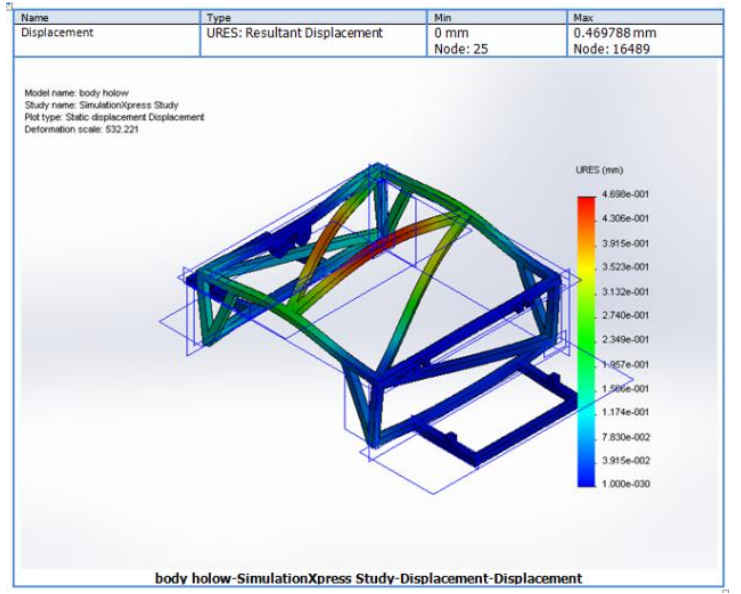

Hal yang sama juga didapatkan pada pengujian pembebanan dalam simulasi ini adalah besarnya displacemen atau lendutan yang akana terjadi pada daerah-daerah rancangan freme kendaraan hybrid-electrict vehicles ini. Yaitu terlihat displacement maksimum yang dijinkan adalah sebesar $0.469788 \mathrm{~mm}$. sehingga secara jelas deformasi yang akan terjadi pada rancangan frame kendaraan ini diperlihatkan secara grafis pada gambar di bawah berikut ini.

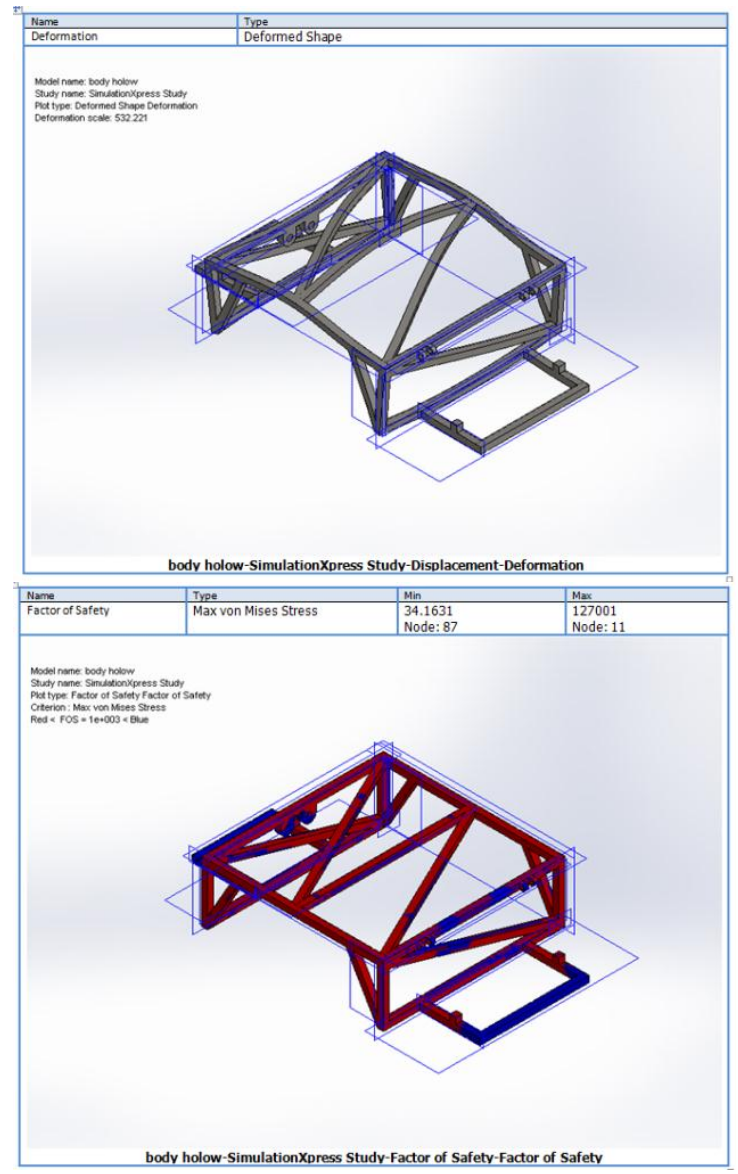

\section{KESIMPULAN}

Dari hasil perancangan frame kendaraan hybrid ini dengan bantuan software solid works dengan mensimulasikan secara menyeluruh perancangan freme ini maka dapat ditarik sebuah kesimpulan sebagai berikut:

1. - Massa frame Kendaraan : 193, 011 $\mathrm{Kg}$

- Volume batang frame : 0,0250663 $\mathrm{m}^{3}$

- Density frame kendaraan: 7700 $\mathrm{kg} / \mathrm{m}^{3}$ 
- Weigth frame kendaraan : 1891,5 N

2. - Row material frame kendaraan : Alloy Steel

- Model freme kendaraan : Linear Elastic Isotropic

- Kreteria kegagalan fare kendaraan : Max von Mises Stress

- Yield strength : 6. $20422 \mathrm{e}^{+008} \mathrm{~N} / \mathrm{m}^{2}$

- Tensile Strength : $7,23826 \mathrm{e}+{ }^{008}$ $\mathrm{N} / \mathrm{m}^{2}$

\section{Hasil perancangan ElectricSystem} kendaraan Hybrid-Electric Vehicles
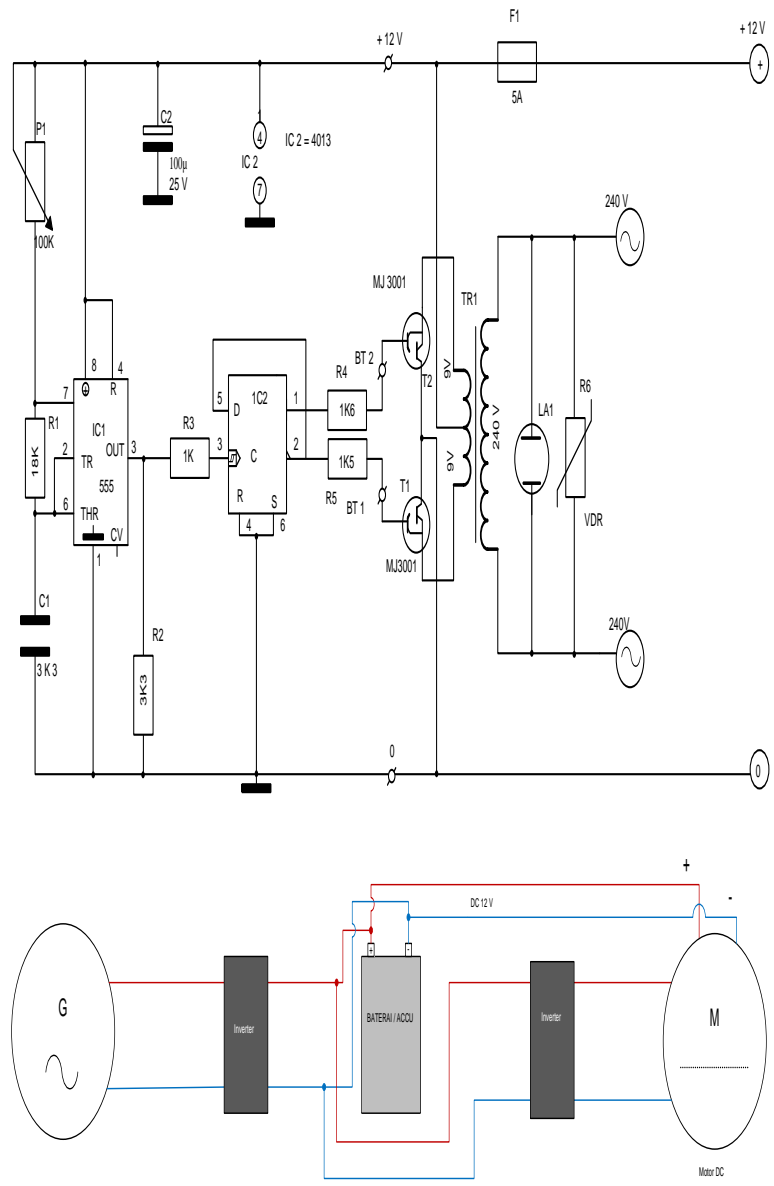

Dari hasil rancangan kelistrikan kendaraan hybrid seperti dapat dilihat di atas, maka peneliti merancang menggunakan dua inverter pada rangkaian ini yang berfungsi untuk mengkonversi arus listrik searah (DC-12V) menjadi arus listrik dua arah (AC-220V). Sehingga arus yang dikeluarkan dari putaran motor bensin yang dan motor DC akan tersimpan di batrai sehingga dua motor ini akan menghasilkan daya listrik yang terbuang dan di simpan di batrai sebagai sumber energy.

\section{Hasil perancangan 3D kendaraan Hybrid-Electric Vehicles \\ a. Tampak Samping}

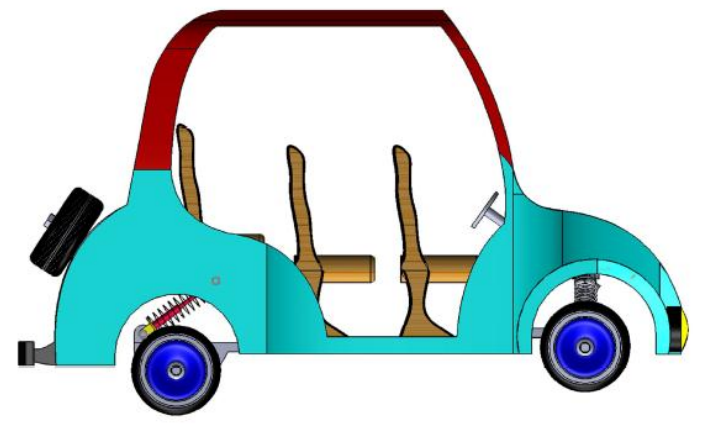

b. Tampak Depan

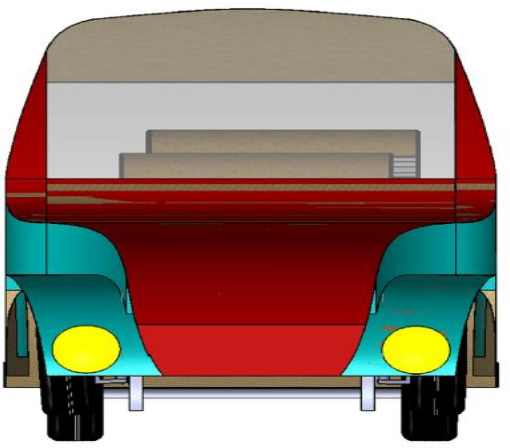

Jurnal Sains dan Teknologi|229 


\section{c. Isometri}

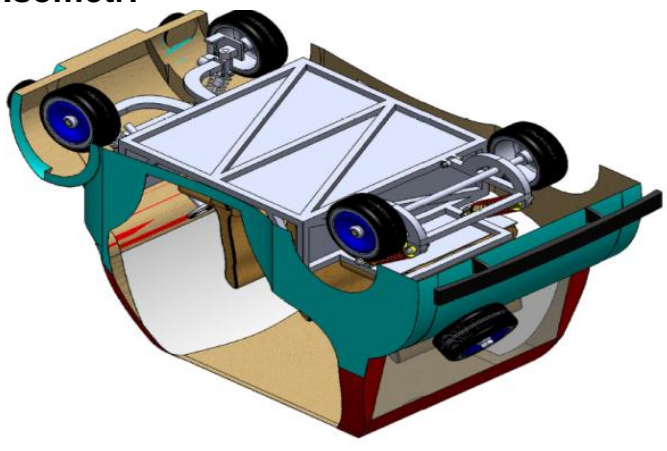

\section{DAFTAR PUSTAKA}

AuYeung, Felix, Elizabeth Drake, John Heywood, Andreas Schafer, and Malcolm Weiss. "On the Road in 2020." Massachusetts Institute of Technology. N.p., n.d. Web. 4 Nov. 2009.

web.mit.edu/energylab/www/pubs/el0 0-003.pdf.

Adner R. and Levinthal D., 2001, 'Demand Heterogeneity and Technology Evolution: Implication for Product and Process Innovation', Management Science, May 2001, Volume 47, Issue 5, pp 611-628 Agenda 21, 1992, 'Earth Summit: Agenda 21', Conference on Environment and Development (UNCED), Rio de Janerio, Brazil, 3 to 14 June 1992, (http://www.un.org/esa/sustdev/docum ents/agenda21/index.htm),

[Accessed: November 21st 2004].

Barbalace, Roberta C. "CO2 Pollution and Global Warming." Environmental Chemistry. 27 Sep. 2009 www.environmentalchemistry.com/yo gi/environmental/200611CO2globalwa rming.html.

Berman, Bradley. "Hybrid Battery Toxicity | Hybrid Cars." New Hybrid Reviews, News \& Hybrid. Mileage (MPG) Info / Hybrid Cars. N.p., n.d. Web. 8 Apr.
2006.

http://www.hybridcars.com/batterytoxicity.html.

Berman, Bradley. "Hybrid Market Forecasts | Hybrid Cars." New Hybrid Reviews, News \& Hybrid Mileage (MPG) Info | Hybrid Cars. 30 Sep. 2009 http://www.hybridcars.com/hybriddrive rs/ hybrid-market-forecasts.html.

Bryant, Charles W. and Karim Nice. "How Catalytic Converters Work"." Howstuffworks "Auto".N.p., n.d. 2008. http://auto.howstuffworks.com/catalyti c-converter1.htm.

Claus Doll, Inovation in Vehicles TecnologyThe Case of Hybrid Electric Vehicles, (Germany: Fraunhofer-Institute for Systems and Innovation Research, 2008).

Desonie, D. (2002). In Robinson R. (Ed.), Global climate change. New York: Macmillan Reference USA. 2 Oct. 2009.

Hopwood, Nick, and Jordan Cohen. "Green House Gases and Society." University of Michigan. N.p., n.d. Web. 4 Nov. 2009.

http://www.umich.edu/ gs265/society/ greenhouse.htm.

Hudson, Mike. Federal Hybrid Tax Credit Programs by Vehicle. Retrieved 19 Oct.

2009.http://www.edmunds.com/fuelec onomy/car-taxcredit.html?mktcat=hybridtaxcredit\&kw=hybrid+tax+credit+2009 \&mktid=ga56677332\&gclid=CNzvgPG 2pp0CFQtN5QodPw6p1w.

Michael Beliveau, James Rehberger, Jonathan Rowell, Alyssa Xarras, "Stydy on Hybrid Car: Enviromental Effects and Consumer Habits", (Worcester Polytecnic. Institute, 2010)

Jurnal Sains dan Teknologi |230 